\title{
Analysis of the use of cupola furnace slags, green sand and reclaimed asphalt pavement in asphalt concrete mixtures for low intensity traffic
}

\section{Hormigón bituminoso compuesto por escoria de horno de cubilote, arenas verdes y material fresado para tráfico de baja intensidad}

Ángel Vega-Zamanillo (Main and Corresponding Author)

Universidad de Cantabria/Escuela de Caminos, Canales y Puertos de Santander/Grupo de Caminos de Santander (GCS) Avda. de Los Castros, s/n, 39005, Santander (Spain)

angel.vega@unican.es

\section{Miguel Ángel Calzada-Pérez}

Universidad de Cantabria/Grupo de Caminos de Santander (GCS) (Spain)

calzadam@unican.es

\section{Pedro Lastra-González}

Universidad de Cantabria/Grupo de Investigación de Tecnología de la Construcción (GITECO) (Spain) pedro.lastragonzalez@unican.es

\section{Irune Indacoechea-Vega}

Universidad de Cantabria/Grupo de Investigación de Tecnología de la Construcción (GITECO) (Spain)

irune.indacoechea@unican.es

\section{José Ángel Fernández-Ortega}

Universidad de Cantabria/Grupo de Investigación de Tecnología de la Construcción (GITECO) (Spain)

joseangel.fernandez@unican.es

\section{Manuscript Code: 651}

Date of Acceptance/Reception: 27.07.2017/17.06.2015

DOI: $10.7764 /$ RDLC.16.2.229

\section{Abstract}

This paper presents the performance of different types of asphalt mixtures containing reclaimed asphalt pavement (RAP) and industrial by-products such as cupola furnace slags and green sands. In this study, conventional bitumen is employed as binding material while limestone is used as natural aggregate. The Marshall method has been used for designing the asphalt mixtures and voids percentage while water sensitivity and wheel tracking tests have been carried out to evaluate the mixtures performance. Although the only natural aggregate is limestone, and this significantly hinders the performance of these mixtures, laboratory results show that they can be successfully employed in the construction of low traffic intensity roads as binder course.

Key words: RAP, cupola slag, green sand, asphalt concrete, bituminous mixture.

\section{Resumen}

Este artículo recoge el rendimiento de diferentes tipos de hormigón bituminoso fabricados con material fresado y residuos industriales: escoria de horno de cubilote y arenas verdes de moldeo. El árido natural empleado es calizo y el ligante es un betún convencional 50/70. Las dosificaciones se han realizado utilizando el método Marshall, los ensayos mecánicos efectuados sobre las mezclas son los requeridos por la normativa española: porcentaje de huecos, sensibilidad al agua y ensayo de rodadura. Aunque la utilización de caliza como único árido natural penaliza el rendimiento de estas mezclas, los resultados han mostrado que pueden llegar a ser viables para capas intermedias de pavimentos de baja intensidad de tráfico.

The suitability of reclaimed asphalt pavement (RAP) as recycled aggregate in the manufacture of bituminous mixes has been widely analysed; however, the performance in asphalt mixtures of industrial by-products as green sands and cupola furnace slags has been less investigated.

This type of slag is developed in the process of cast iron production and has been successfully used in constructed wetlands for the purification of wastewater (Saeed, Afrin, Muyeed \& Sun, 2012) as well as in the manufacture of concrete by replacing both the aggregate (Zachar \& Naik, 2010) and the cement (Ceccato, Masuero, Moraes, \& Vilela, 2009). Regarding road construction, its use is basically limited to replace materials of the road bed (Andrews, Gikunoo, 
Ofosu-Mensah, Tofah, \& Bansah, 2012; Mandeep, 2014), its application in bituminous mixes has not been deeply analysed, and its utilization rate stays far from the rates of other industrial by-products as the slags coming from blast or electric-arc furnaces.

The second material considered in this study is green sand, commonly used in the metal industry for mold casting in which the molten steel, coming from the furnace, is poured. This material is repeatedly reused in the casting process until the loss of properties forces its replacement. It is mainly composed of silica sand (85 - 95\%), bentonite (4-10\%), additives (2 - 10\%) and water (2 - 5\%) (Siddique \& Singh, 2011). The type and concentration of some components can greatly change depending on the metal industry where the green sand is used. In the case of the casting process, the metal concentration in the sand is similar to the concentration found in an agricultural land (Bradshaw, Benson, Olenbush, \& Melton, 2010). Previous studies indicate that this type of waste can be suitably used as cropland (Hindman, Stehouwer, \& Macneal, 2008).

In the construction sector, green sands have been used as base material in linear works improving some properties of natural sands (Guney, Aydilek, \& Demirkan, 2006). They were also investigated as fine aggregate replacement in asphalt concretes. A maximum rate of utilization of $10 \%$ was obtained, higher percentages get worse the performance of the mixtures (Bakis, Koyuncu, \& Demirbas, 2006).

This by-products should be also analysed from an environmental point of view before to be used in a real road, different tests are recommended to check if they pose environmental risks (Maghool, Arulrajah, Du, Horpibulsuk, \& Chinkulkijniwat, 2017). Leaching and expansiveness tests are usually required with this type of materials to avoid future problems (Kambole, Paige-Green, Kupolati, Ndambuki, \& Adeboje, 2017).

Finally, RAP coming from the milling of the pavements' wearing course will include aggregates and bitumen in its composition. There is not a consensus about the amount of residual bitumen that blends with the virgin bitumen, but it has been estimated that an addition of $25-30 \%$ of RAP in the mixture allows savings of approximately $1 \%$ of virgin bitumen (Avilés Lorenzo, 2002).

There are two main techniques to incorporate RAP into bituminous mixes: in-situ recycling, where the milled material is directly reused on site by adding new aggregates, bitumen or additives; and in-plant recycling, where the milled material is hauled to an asphalt plant and used as raw material for the construction of new mixes.

Recently, the Spanish specifications have been modified and the percentage of RAP that can be used in asphalt mixtures has been increased. Currently, there are three levels of RAP allowed in the Spanish specifications: less than $15 \%$ by weight of the mixture, there are not special requirements. From $15 \%$ to $60 \%$ by weight of the mixture, in this case the RAP has to been added in an asphalt plant (recycling in situ is not allowed), and besides the conventional tests, the homogeneity of the RAP and more restricted tests are required. Finally, is possible to use more than $60 \%$ of RAP in a bituminous mixture, but it is necessary a specific study of the project and the permission of Public Roads Administration. Despite this increase in the percentage of RAP allowed, this new law still authorises the use of RAP only in binder and base courses, never in wearing courses (Ministerio de Obras Públicas, 2015).

Several experimental stretches have been built with high rates of RAP. Thus, rates higher than $50 \%$ were used in binder and base courses along the Fenix Project (Valdés, Martínez, \& Pérez-Jiménez, 2008). The results obtained led to the conclusion that both the Marshall stability and granulometric variability tend to grow as new RAP is incorporated. On the other hand, the later is reduced as the amount of RAP is used, which means that the variability induced in the grading by the RAP can be controlled just by limiting the maximum aggregate size (MAS) of the recycled aggregates.

But RAP has also been used in wearing courses. $10 \%$ was included in a HMA by applying the Superpave method (Solanki, Zaman, Adje, \& Hossain, 2013), getting to the conclusion that incorporating recycled material led to a greater resistance to plastic deformation, a lower susceptibility to fatigue cracking and a mitigation of the effect of the water action on the mix. Nevertheless, it also led to a worse response to low temperature cracking.

Regarding the interaction between the RAP residual binder and the virgin binder, a research was done in 2005 in which RAP was heated up during 2, 3.5 and 8 hours before mixing the material. Results showed that if RAP pre-heating time is too short, the residual and virgin binders are not able to reach the properties of a suitable mix. On the contrary, if the pre-heating period is too large, the residual binder hardens and many of its particles are not able to interact with the new binder. This implies that there is an optimum temperature to mix the RAP binder and the virgin binder. Out of this temperature, the RAP would only act as an aggregate, leading to higher compaction efforts and voids percentages (Daniel \& Lachance, 2005). Other authors are working to recover the properties of the residual 
binder, generating in this way a binder with the same properties as the original one. For this aim, rejuvenating agents as vegetal oils, aromatic oils or soft bitumensare being used together with the virgin oil (Dony, Colin, Bruneau, Drouadaine, \& Navaro, 2013).

\section{Description of the problem}

Currently, the construction of roads has a high economic and environmental impact, with a significant amount of natural resources required. The replacement of virgin materials, without compromising the efficiency and technical performance, means an improvement in the sustainability of the road sector.

This paper assesses the behaviour of bituminous mixtures that incorporate three different types of recycled materials (RAP, cupola slags and green sands), used in different percentages with limestone as only natural aggregate, and conventional bitumen (50/70 penetration grade), with the aim of achieving bituminous mixtures with good mechanical performance and lower percentage of natural aggregates.

Materials

The natural aggregate is entirely made up of limestone and is divided in five different fractions whose grading is presented in Table 1. Regarding its properties, a Flakiness Index of 11.9 (EN 933-3), a Los Angeles coefficient of 25 (EN 1097-2) and a Polished Stone Value (PSV) of 34 (EN 1097-8) were obtained.

Table 1. Accumulated sieve (\% on mass) of the natural aggregate. Source: Personal compilation, 2014.
\begin{tabular}{lccccccccc} 
Fraction & 22 & 16 & 8 & 4 & 2 & 0.5 & 0.25 & 0.063 \\
\hline $0-6 \mathrm{~mm}$ & 100.0 & 100.0 & 100.0 & 83.7 & 58.9 & 27.2 & 19.2 & 10.2 \\
$6-12 \mathrm{~mm}$ & 100.0 & 100.0 & 59.7 & 3.3 & 2.3 & 1.9 & 1.8 & 1.5 \\
$12-18 \mathrm{~mm}$ & 100.0 & 83.8 & 1.2 & 0.3 & 0.3 & 0.3 & 0.3 & 0.2 \\
$18-25 \mathrm{~mm}$ & 80.0 & 9.1 & 3.4 & 2.6 & 2.5 & 2.2 & 2.1 & 1.6 \\
$25-40 \mathrm{~mm}$ & 65.5 & 14.3 & 5.9 & 4.3 & 3.6 & 2.7 & 2.4 & 2.0 \\
\hline
\end{tabular}

A conventional bitumen 50/70 was employed while the alternative aggregates were supplied by a factory located in Cantabria, Spain. The residual aggregates are made up of industrial by-products: furnace slags, with a density of 2.680 $\mathrm{g} / \mathrm{cm}^{3}$ (EN 1097-6), and green sands, with a density of $2.506 \mathrm{~g} / \mathrm{cm}^{3}$ (EN 1097-6). Besides, milled material coming from a rejected asphalt mixture was also used, this RAP contains 3,9\% of residual binder by weight and it is supposed to have good mechanical properties due to its nature (ophite as coarse aggregate and limestone as fine aggregate). The sand equivalent test (EN 933-8) was done on a fine aggregate sample, made up both of limestone and slags, green sands and RAP. The test resulted in an average value of 61. The particle size distribution (EN 933-1) of every residual material is shown in Table 2.

\begin{tabular}{lccccccccc} 
Table 2. Accumulated sieve by weight of the slags, green sands and RAP. Source: Personal compilation, 2014 \\
\hline Material & 22 & 16 & 8 & 4 & 2 & 0.5 & 0.25 & 0.063 \\
\hline RAP & 97.1 & 93.7 & 72.8 & 49.7 & 30.8 & 7.0 & 2.5 & 0.4 \\
Slag & 100.0 & 100.0 & 99.7 & 95.8 & 76.6 & 13.5 & 3.9 & 0.5 \\
Green Sand & 100.0 & 100.0 & 100.0 & 100.0 & 99.9 & 82.7 & 7.1 & 0.2 \\
\hline
\end{tabular}

\section{Methodology}

Spanish specifications were used for the gradation of the mixture and the limestone aggregate characterization. The Marshall method was used and voids content, cohesion loss due to water action and resistance to plastic deformations were calculated as established in Spanish standard PG-3 (Ministerio de Fomento, 2008).

Different types of mixtures were designed, depending on their performance they can be used in different levels of heavy traffic. The different categories of heavy traffic of the Spanish standard are presented in Table 3. 
Table 3. Heavy traffic categories. Source: 6.1-IC Secciones de firme. Orden FOM/3460/2003

\begin{tabular}{lcccccc}
\hline Traffic level & T00 & T0 & T1 & T2 & T3 & T4 \\
\hline $\begin{array}{l}\text { Heavy } \\
\text { vehicle/day }\end{array}$ & $\geq 4000$ & $3999-2000$ & $1999-800$ & $799-200$ & $199-50$ & $<49$ \\
\hline
\end{tabular}

Four mixes were produced for the different asphalt courses: wearing, binder and base course. They result from the variation of parameters such as the maximum aggregate size and the rate of residual material employed. During the mixture gradation, a fragmentation of the aggregates occurred. More exactly, the slags, and the limestone aggregates to a lesser extent, suffered breakage; it occurred during the Marshall compaction process, resulting in a significant variation of the mixture final grading as compared with the theoretical. From that moment on, this factor was considered for the asphalt mix gradations carried out, in such a way the mixture grading after compaction was the required one. To that end, the theoretical particle size distribution was approximated to the lower limit set by the Spanish specifications (Ministerio de Fomento, 2008) for each type of mixture. The granulometric analysis of the mixes was performed by recovering the binder with perchlorethylene. The grading of the recovered mixture is presented later together with the theoretical one used for the mixture design.

The slags wear resistance can be visually verified in Figure 1. The left tray contains slag coming directly from the stockpile while the right tray contains the same slag once it has been tamped down with a metal plate. It can be seen how the material broke up into smaller particles, leading to an almost uniform grading.

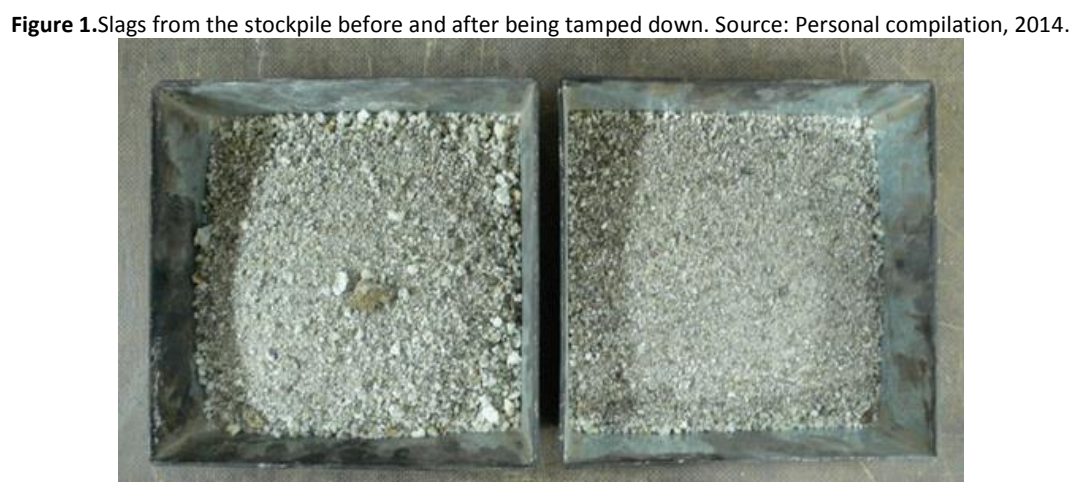

A $10 \%$ of milled material was decided to be used in the experimental mixtures, which coincides with the limit value allowed by the Spanish regulations. The same percentage was taken for the industrial by-products, setting in this way an upper limit of $10 \%$ for furnace slags and green sands. Nevertheless, a higher amount of recycled aggregate was used in the mixture for binder courses. In this case, a $45 \%$ of recycled material was incorporated to the mixture. The mixtures tested in the laboratory are presented in Table 4.

Table 4. Tested mixtures. Source: Personal compilation, 2014.

\begin{tabular}{lccccc}
\hline \multicolumn{6}{c}{ Table 4. Tested mixtures. Source: Personal compilation, 2014.} \\
Name & $\begin{array}{c}\text { Type of } \\
\text { Course }\end{array}$ & $\begin{array}{c}\text { RAP } \\
\text { content } \\
{[\%]}\end{array}$ & $\begin{array}{c}\text { Slag } \\
\text { content } \\
{[\%]}\end{array}$ & $\begin{array}{c}\text { Green Sands } \\
\text { content } \\
{[\%]}\end{array}$ \\
\hline AC16 Surf 50/70 S & Wearing & $50 / 70$ & 10 & 5 & 5 \\
AC22 Surf 50/70 S & Wearing & $50 / 70$ & 10 & 5 & 5 \\
AC22 Bin 50/70 S & Binder & $50 / 70$ & 30 & 5 & 10 \\
AC22 Base 50/70 G & Base & $50 / 70$ & 10 & 5 & 5 \\
\hline
\end{tabular}




\section{Wearing course}

AC-16-Surf $50 / 70 \mathrm{~S}$. This mixture is composed by $10 \%$ reclaimed asphalt, $5 \%$ green sand and $5 \%$ slag. In Table 5 the granulometric difference may be seen that is produced after the compaction.

\begin{tabular}{ccccccccc}
\multicolumn{8}{c}{ Table 5.Granulometric variation due to the mixture compaction. Source: Personal compilation, 2014.} \\
\hline \multicolumn{10}{c}{ AC-16-Surf S } \\
\hline Grading Sieve (mm) & 22 & 16 & 8 & 4 & 2 & 0.5 & 0.25 & 0.063 \\
Original & 100.0 & 92.7 & 64.5 & 39.2 & 27.8 & 13.8 & 8.8 & 4.6 \\
Recovered & 100.0 & 92.7 & 71.5 & 46.8 & 36.0 & 20.1 & 13.0 & 7.1 \\
\hline
\end{tabular}

It is composed by $4.5 \%$ of bitumen on mixture and reached a density of $2.377 \mathrm{~g} / \mathrm{cm}^{3}$. In the wheel tracking test, the specimens were $50 \mathrm{~mm}$ thick. The mechanical results and the limits of the Spanish standard are included in the Table 6.

\begin{tabular}{|c|c|c|}
\hline & AC 16 Surf 50/70 S & Spanish Standard \\
\hline \multicolumn{3}{|l|}{ Voids test (EN 12697 - 8) } \\
\hline Voids in mixture (\%) & 5.4 & $4-6$ \\
\hline Voids in aggregates (\%) & 15.7 & $\geq 15$ \\
\hline \multicolumn{3}{|c|}{ Water sensitivity test (EN $12697-12$ ) } \\
\hline ITS Dry (MPa) & 1.859 & - \\
\hline ITS Wet (MPa) & 1.412 & - \\
\hline ITSR (\%) & 94 & $\geq 85$ \\
\hline \multicolumn{3}{|c|}{ Wheel tracking test (EN $12697-22$ ) } \\
\hline Slope (mm/1000 cycles) & 0.07 & $\leq 0.07^{1}$ \\
\hline Tracking depth (mm) & 3.0 & - \\
\hline
\end{tabular}

This mixture fulfilled the mechanical requirements at laboratory level to be used in any road, independently of the heavy traffic level and climate conditions.

AC-22-Surf 50/70 S. This mixture is composed by $10 \%$ reclaimed asphalt, $5 \%$ green sand and $5 \%$ slag. Table 7 shows the granulometric difference after compacting the sample.

Table 7.Granulometric difference due to compaction of the mixture. Source: Personal compilation, 2014.

\begin{tabular}{cccccccccccc}
\hline \multicolumn{10}{c}{ AC-22-Surf S } \\
\hline Grading & Sieve (mm) & 32 & 22 & 16 & 8 & 4 & 2 & 0.5 & 0.25 & 0.063 \\
& Original & 100.0 & 90.7 & 73.4 & 53.3 & 38.5 & 23.1 & 10.3 & 5.5 & 4.3 \\
& & & & & & & & & & & \\
& Recovered & 98.3 & 93.7 & 77.7 & 56.3 & 42.3 & 28.3 & 15.0 & 9.0 & 6.1 \\
\hline
\end{tabular}


The percentage of bitumen on mixture is $4.6 \%$, with a density of $2,377 \mathrm{~g} / \mathrm{cm}^{3}$. Due to the increase of the maximal aggregate size, specimens were $60 \mathrm{~mm}$ thick for the wheel tracking test. The mechanical performance of this mixture is presented in the Table 8.

This mixture, with a higher thickness, has reduced significantly the resistance against plastic deformations, so its use is limited to medium and mild weather and light traffics.

Table 8. Mechanical performance of AC 22 Surf 50/70 S. Source: Personal compilation, 2014

\begin{tabular}{|c|c|c|}
\hline & AC 16 Surf 50/70 S & Spanish Standard \\
\hline \multicolumn{3}{|l|}{ Voids test (EN $12697-8$ ) } \\
\hline Voids in mixture (\%) & 5.0 & $4-6$ \\
\hline Voids in aggregates (\%) & 15.5 & $\geq 14$ \\
\hline \multicolumn{3}{|c|}{ Water sensitivity test (EN 12697 - 12) } \\
\hline ITS Dry (MPa) & 1.281 & - \\
\hline ITS Wet (MPa) & 1.126 & - \\
\hline ITSR (\%) & 88 & $\geq 85$ \\
\hline \multicolumn{3}{|c|}{ Wheel tracking test (EN 12697 - 22) } \\
\hline Slope (mm/1000 cycles) & 0.11 & $\leq 0.15^{1}$ \\
\hline Tracking depth (mm) & 3.5 & - \\
\hline
\end{tabular}

${ }^{1}$ Limit for the T3 heavy traffic level of medium and mild weather.

\section{Binder Course}

AC-22-Bin $50 / 70$ S. This mixture is composed by $30 \%$ reclaimed asphalt, $5 \%$ green sand and $10 \%$ slag.

\begin{tabular}{ccccccccccc}
\multicolumn{10}{c}{ Table 9.Granulometric variation due to compaction of the mixture. Source: Personal compilation, 2014.} \\
\hline \multicolumn{110}{c}{ AC-22-Bin S } \\
\hline Grading & Sieve (mm) & 32 & 22 & 16 & 8 & 4 & 2 & 0.5 & 0.25 & 0.063 \\
& Original & 100.0 & 92.1 & 76.1 & 53.8 & 37.2 & 26.1 & 13.5 & 6.9 & 4.4 \\
& Recovered & 100.0 & 93.5 & 80.8 & 56.9 & 37.7 & 27.6 & 15.7 & 8.5 & 6.4 \\
\hline
\end{tabular}

The optimal bitumen dosage was $4.4 \%$ on mixture, obtaining a density of $2.369 \mathrm{~g} / \mathrm{cm}^{3}$. In the water sensitivity test, the conditioned specimen that had been swamped in water got an indirect tensile strength higher than the dry, obtaining a conserved resistance rate of $105 \%$. In the wheel tracking test the thickness was $60 \mathrm{~mm}$. The results are presented in Table 10.

\begin{tabular}{|c|c|c|}
\hline & AC 16 Surf 50/70 S & Spanish Standard \\
\hline \multicolumn{3}{|l|}{ Voids test (EN $12697-8)$} \\
\hline Voids in mixture (\%) & 5.0 & $4-6$ \\
\hline Voids in aggregates (\%) & 15.1 & $\geq 14$ \\
\hline \multicolumn{3}{|c|}{ Water sensitivity test (EN $12697-12$ ) } \\
\hline ITS Dry (MPa) & 1.381 & - \\
\hline ITS Wet (MPa) & 1.445 & - \\
\hline ITSR (\%) & 105 & $\geq 80$ \\
\hline \multicolumn{3}{|c|}{ Wheel tracking test (EN $12697-22$ ) } \\
\hline Slope (mm/1000 cycles) & 0.10 & $\leq 0.10^{1}$ \\
\hline Tracking depth (mm) & 3.8 & - \\
\hline
\end{tabular}


In this case, the mixture also fulfilled the performance for the heaviest traffic level, but in the mild weather. If this mixture is going to be used in the warmest area, the heavy traffic level should be limited to T3 category.

\section{Base Course}

AC-22-Base $50 / 70 \mathrm{G}$. This mixture is made up of $10 \%$ reclaimed asphalt, $5 \%$ green sand and $5 \%$ slag.

Table 11.Granulometric variation due to compaction of the mixture. Source: Personal compilation, 2014.

\begin{tabular}{ccccccccccc}
\hline \multicolumn{10}{c}{ AC-22-Base G } \\
\hline \multirow{2}{*}{ Grading } & Sieve (mm) & 32 & 22 & 16 & 8 & 4 & 2 & 0.5 & 0.25 & 0.063 \\
& Original & 100.0 & 94.7 & 72.4 & 48.3 & 32.8 & 21.9 & 10.5 & 5.8 & 2.1 \\
& Recovered & 100.0 & 94.9 & 81.1 & 60.4 & 42.5 & 31.2 & 16.3 & 9.6 & 4.0 \\
\hline
\end{tabular}

The mixture density is $2.369 \mathrm{~g} / \mathrm{cm}^{3}$, with a binder dosage of $3.9 \%$ on mixture. In the wheel tracking test, due to it is a base mixture, a specimen was used $70 \mathrm{~mm}$ thick. Table 12 shows the mechanical performance of this mixture.

Table 12. Mechanical performance of AC 22 Base 50/70 G. Source: Personal compilation, 2014.

\section{AC 16 Surf 50/70 S Spanish Standard}

\begin{tabular}{lcc}
\hline $\begin{array}{l}\text { Voids test (EN 12697 - 8) } \\
\text { Voids in mixture (\%) }\end{array}$ & 4.7 & $\geq 14$ \\
Voids in aggregates (\%) & 14.5 & \\
Water sensitivity test (EN 12697 - 12) & & - \\
ITS Dry (MPa) & 1.677 & - \\
ITS Wet (MPa) & 1.187 & $\geq 80$ \\
ITSR (\%) & 71 & $\leq 0.10^{1}$ \\
Wheel tracking test (EN 12697 - 22) & & - \\
Slope (mm/1000 cycles) & 0.29 & \\
Tracking depth (mm) & 6.9 &
\end{tabular}

${ }^{1}$ Limit of the highest heavy traffic level of mild weather.

This mixture does not fulfilled the mechanical requirements of the Spanish standard. As the maximal aggregate size and the layer thickness improve, the mineral skeleton formed by the coarse fraction becomes a more relevant factor. For this reason, the mixture performance is better for thicknesses not above $60 \mathrm{~mm}$, value from which the low limestone Los Angeles coefficient punishes the mixture resistance, reducing the conserved resistance due to the bad coating produced by its fragmentation during the compaction (Figure 2), and increasing the plastic deformations.

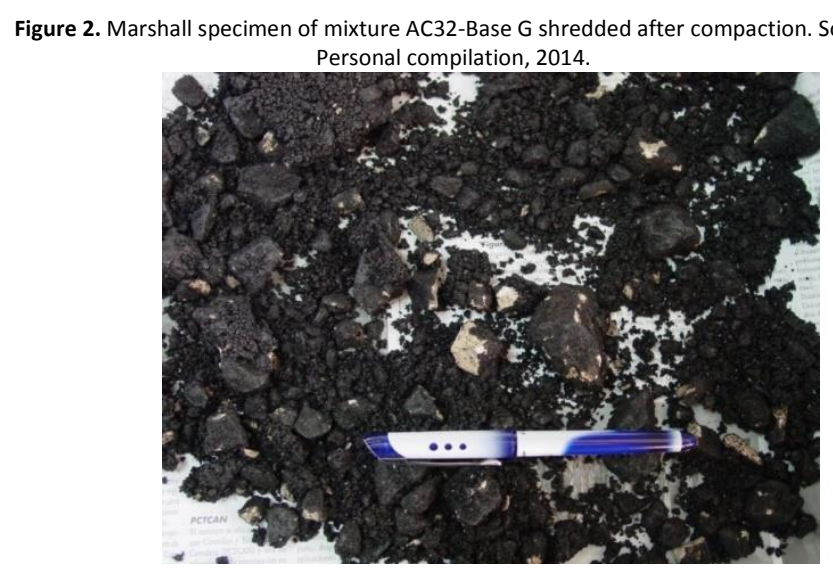


The resistance against plastic deformation can be analysed in Figure 3, which presents the results of the Wheel tracking tests. It shows how the plastic deformation is increased when the thickness is higher.

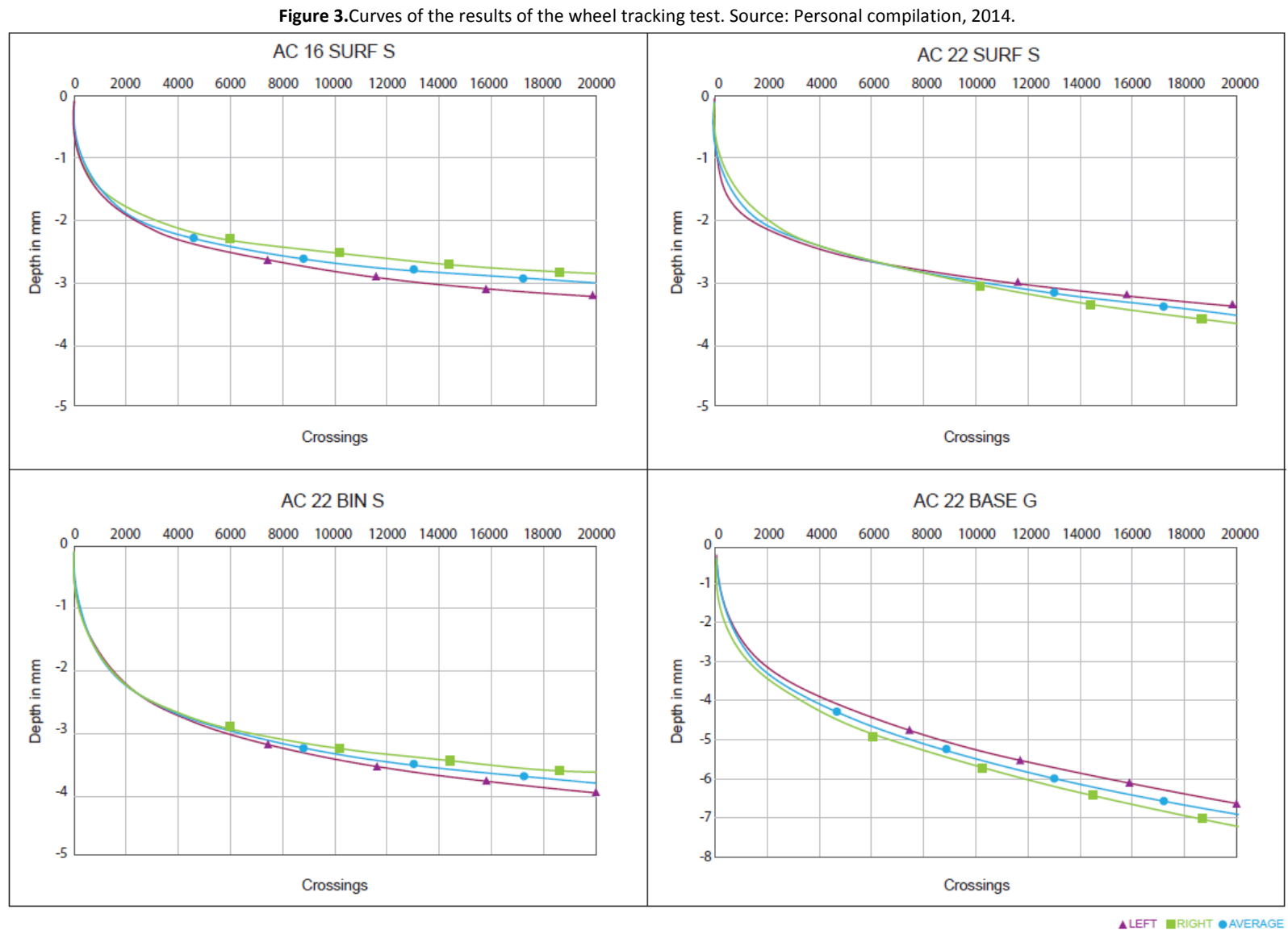

The slag mechanical features prevent their use in rates higher than $10 \%$. Their fragmentation during compaction causes granulometric variations that make the design difficult, and which in case of not being taken into account provoke the voids decrease and plastic deformations due to the lack of internal friction/gripping of the mineral skeleton. This granulometric variation is the reason for dosing the mixtures fitting them to the minimal granulometric spindle that the norm establishes.

The studied mixture AC-16-Surf S satisfactorily fulfills all the requirements imposed by the Spanish norm referring to voids in mixture, voids in aggregates, conserved resistance and plastic deformations. Its use would be suitable for mean heavy traffic taking into account the mechanical results. However, the fact of using limestone as coarse aggregate and because it is highly polishable, prevents the use of the mixture in this type of roads and limits it for areas of low density such as hard shoulders, parking lots and some kinds of urban roads of low speed, where the slip resistance is not a limiting factor.

The mixture AC-22-Surf S would only fit slight traffics type T4. It fulfills the technical requirements in relation to voids and keeps a good conserved resistance; however, its resistance to plastic deformations gets noticeably worse respect the mixture with AC-16-Surf S. Its use would be limited to wearing courses where there is hardly any heavy traffic or areas where the resistant commitment is not high.

The mixture AC-22-Bin S does not directly contact the vehicles tires, so that the low PSV of limestone is not a restraining restriction anymore. The good value of water sensitivity test probably is linked with the greater percentage of RAP used, this type of aggregate is pre-coated and it usually improves the resistance. This mixture fulfills all the requirements for light traffics $\mathrm{T} 2$ or below. 
The mixture AC-22-Base $\mathrm{G}$ does not reach the minimal water sensitivity requirements nor the plastic deformations. It would be necessary to replace the limestone by other coarse aggregate of better quality to improve the mixture performance.

The authors wish to acknowledge ARRUTI S.A. for their collaboration on the project.

Andrews, A., Gikunoo, E., Ofosu-Mensah, H., Tofah, H., \& Bansah, S. (2012). Chemical and Mineralogical Characterization of Ghanaian Foundry Slags. Journal of Minerals \& Materials characterization \& Engineering, 11(2), 183-192.

Avilés Lorenzo, J. (2002). Estudio de la tenacidad de los microaglomerados reciclados en caliente mediante el ensayo BTD. Efecto del tipo y contenido de betún. Departament d'Infraestructura del Transport i del Territori, Universidad Politécnica de Cataluña.

Bakis, R., Koyuncu, H., \& Demirbas, A. (2006). An investigation of waste foundry sand in asphalt concrete mixtures. Waste Management and Research, 24(3), 269-274. https://doi.org/10.1177/0734242X06064822

Bradshaw, S. L., Benson, C. H., Olenbush, E. H., \& Melton, J. S. (2010). Using foundry sand in green infrastructure construction. Green Streets and Highways 2010: An Interactive Conference on the State of the Art and how to Achieve Sustainable Outcomes - Proceedings of the Green Streets and Highways 2010 Conference, 389 280-298.

Ceccato, D. M., Masuero, A. B., Moraes, C. A. M., \& Vilela, A. C. F. (2009). The recycling of Foundry granulated slag (FGS) as a partial substitute of cement in concrete. [Reciclaje de escoria granulada de fundición (egf) como sustitución de parte del cemento en hormigón].Revista Materia, 14(1), 737-748.

Daniel, J. S., \& Lachance, A. (2005). Mechanistic and volumetric properties of asphalt mixtures with recycled asphalt pavement. Transportation Research Record, 1929, 28-36. https://doi.org/10.3141/1929-04

Dony, A., Colin, J., Bruneau, D., Drouadaine, I., \& Navaro, J. (2013). Reclaimed asphalt concretes with high recycling rates: Changes in reclaimed binder properties according to rejuvenating agent. Construction and Building Materials, 41, $175-181$. https://doi.org/10.1016/j.conbuildmat.2012.11.031

Guney, Y., Aydilek, A. H., \& Demirkan, M. M. (2006). Geoenvironmental behavior of foundry sand amended mixtures for highway subbases. Waste Management, 26(9), 932-945. https://doi.org/10.1016/j.wasman.2005.06.007

Hindman, J., Stehouwer, R., \& Macneal, K. (2008). Spent foundry sand and compost in blended topsoil: Availability of nutrients and trace elements. Journal of Residuals Science and Technology, 5(2), 77-86.

Kambole, C., Paige-Green, P., Kupolati, W. K., Ndambuki, J. M., \& Adeboje, A. O. (2017). Basic oxygen furnace slag for road pavements: A review of material characteristics and performance for effective utilisation in southern Africa. Construction and Building Materials, 148, 618-631. https://doi.org/10.1016/j.conbuildmat.2017.05.036

Maghool, F., Arulrajah, A., Du, Y. -., Horpibulsuk, S., \& Chinkulkijniwat, A. (2017). Environmental impacts of utilizing waste steel slag aggregates as recycled road construction materials. Clean Technologies and Environmental Policy, 19(4), 949-958. https://doi.org/10.1007/s10098-016-12896.

Mandeep, S. (2014). Utilization of cupola furnace slag as partial replacement to coarse aggregates in concrete mix. Thapar University, India. 1-58.

Ministerio de Fomento. (2008). Orden circular 24/2008 sobre el pliego de prescripciones técnicas generales para obras de carreteras y puentes (PG3). Artículos: 542 - Mezclas bituminosas en caliente de tipo hormigón bituminoso; y 543 - Mezclas bituminosas para capas de rodadura. Mezclas drenantes y discontinuas. Madrid, España. Secretaría de Estado de Infraestructuras, Transporte y Vivienda.

Ministerio de Fomento. (2015). Orden FOM/2523/2014, por la que se actualizan determinados artículos del pliego de prescripciones técnicas generales para obras de carreteras y puentes, relativos a materiales básicos, a firmes y pavimentos, y a señalización, balizamiento y sistemas de contención de vehículos. Madrid, España. Secretaría de Estado de Infraestructuras, Transporte y Vivienda.

Saeed, T., Afrin, R., Muyeed, A. A., \& Sun, G. (2012). Treatment of tannery wastewater in a pilot-scale hybrid constructed wetland system in Bangladesh. Chemosphere, 88(9), 1065-1073. https://doi.org/10.1016/j.chemosphere.2012.04.055

Siddique, R., \& Singh, G. (2011). Utilization of waste foundry sand (WFS) in concrete manufacturing. Resources, Conservation and Recycling, 55(11), 885-892. https://doi.org/10.1016/j.resconrec.2011.05.001

Solanki, P., Zaman, M., Adje, D., \& Hossain, Z. (2013). Field construction and mechanistic performance of hot mix asphalt containing reclaimed asphalt pavement. International Journal of Pavement Research and Technology, 6(4), 403-413. https://doi.org/10.6135/ijprt.org.tw/2013.6(4).403

Valdés, G., Martínez, A., \& Pérez-Jiménez, F. (2008). Variability study of hot-mix asphalt with high rates of reclaimed asphalt pavement (RAP). [Estudio de Variabilidad en Mezclas Asfálticas en Caliente Fabricadas con Altas Tasas de Material Asfáltico Reciclable (RAP)] Revista de la Construcción, 7(1), 60-71. 